\title{
Meat tenderness and muscle growth: is there any relationship? ${ }^{\text {is }}$
}

\author{
Mohammad Koohmaraie*, Matthew P. Kent, Steven D. Shackelford, Eva Veiseth, \\ Tommy L. Wheeler
}

US Meat Animal Research Center, ARS, USDA, PO Box 166, Spur 18-D, Clay Center, NE 68933-0166, USA

Received 19 March 2002; received in revised form 8 April 2002; accepted 22 April 2002

\begin{abstract}
Our objectives for this manuscript are to review the mechanisms of muscle growth, the biological basis of meat tenderness, and the relationship between these two processes. Muscle growth is determined by hyperplasia and hypertrophy. Muscle cell size is determined by the balance between the amount of muscle protein synthesized and the amount of muscle protein degraded. Current evidence suggests that the calpain proteolytic system is a major regulator of muscle protein degradation. Sarcomere length, connective tissue content, and proteolysis of myofibrils and associated proteins account for most, if not all, of the explainable variation in tenderness of meat after postmortem storage. The relative contribution of each of the above components is muscle dependent. The calpain proteolytic system is a key regulator of postmortem proteolysis. While changes in muscle protein degradation affect meat tenderization/tenderness, changes in muscle protein synthesis are not expected to affect meat tenderization/tenderness. Published by Elsevier Science Ltd.
\end{abstract}

Keywords: Meat; Muscle; Growth; Tenderness; Synthesis; Degradation; Calpain

\section{Introduction}

To meet consumer expectations, the United States meat industry has identified solving the problem of inconsistent meat tenderness as a top priority. This requires a detailed understanding of the processes that affect meat tenderness and, perhaps more importantly, the utilization of such information by the meat industry. Beginning with the decade of the 1990s, the United States meat industry has accelerated the adoption of new technologies to meet consumer expectations. For example, while beef products from several companies now carry the label of 'guaranteed tender,' just a few years ago such products could not be found in any retail case. Other recent developments include the use of marinades and case-ready products. These recent devel-

\footnotetext{
Names are necessary to report factually on available data; however, the USDA neither guarantees nor warrants the standard of the product, and the use of the name by USDA implies no approval of the product to the exclusion of others that may also be suitable.

* Corresponding author. Tel.: + 1-402-762-4221; fax: + 1-402-7624149 .

E-mail address: koohmaraie@email.marc.usda.gov (M. Koohmaraie).
}

opments indicate the increased likelihood of adoption of new technologies by the United States meat industry to improve consistency in meat tenderness.

Eating satisfaction results from the interaction of tenderness, juiciness, and flavor. However, as outlined previously (Koohmaraie, 1995), there is little variation in juiciness and flavor of beef under production practices in the United States; therefore, reduction/elimination of tenderness variation should result in reduction/ elimination of variation in eating quality. The objectives of this manuscript are to review the mechanisms of muscle growth, the biochemical basis for meat tenderness, and the relationship between these two important processes. This is not meant to be a comprehensive review of the literature.

\subsection{An unrelated but noteworthy observation}

There seems to be a trend among many to put improper importance on a mean for a given trait of a given study. For example, it is very common to see statements to the effect that a given percentage of meat tenderization occurs by day 1 postmortem, or that no change in meat tenderization occurs by day 3 postmortem, or most of the meat tenderization occurs after 
day 3 postmortem and since calpain has lost most of its activity, it cannot be involved in postmortem meat tenderization. The fact is that none of these changes occur uniformly among animals and to assume that they do is to underestimate the dynamic nature of postmortem changes. To illustrate this point, consider the data we generated a number of years ago to demonstrate the changes in shear force value of cooked lamb longissimus from slaughter until 14 days of postmortem storage (Fig. 1 a, b; Wheeler and Koohmaraie, 1994). The mean shear force value at $24 \mathrm{~h}$ postmortem was $8.66 \mathrm{~kg}$. One could look at this data and conclude that at $24 \mathrm{~h}$ postmortem meat is very tough, that tenderization has not yet occurred, and that tenderization will begin sometime after $24 \mathrm{~h}$ of postmortem storage (Fig. 1a). If one plots the same curve for each individual lamb, an entirely different interpretation emerges (Fig. 1b). The range in shear force values at $24 \mathrm{~h}$ postmortem was from 5 to 13 kg. Similar information was presented in Fig. 1a as standard deviation (SD $2.01 \mathrm{~kg}$ ), but often when discussing the literature the SD is entirely ignored and mean is the only data considered. It is important to avoid such generalizations and oversimplifications that can lead to erroneous conclusions. In this example, three of 11 sheep are very tender at $24 \mathrm{~h}$, two acceptable and six tough, so for five of 11 animals extensive tenderization has occurred in the first $24 \mathrm{~h}$.

\section{Muscle growth}

Hyperplasia (increase in cell number) and hypertrophy (increase in cell size) are the determinants of muscle mass. If we define hyperplasia as the actual number of cells, this trait is controlled by embryonic cell proliferation. However, if hyperplasia is defined as the DNA content, then it is determined by the prenatal cell proliferation and postnatal growth and development of satellite cells. Therefore, animals born with a greater number of muscle cells (e.g., double muscled cattle) have greater muscling potential. Also, animals in which satellite cells are more active could potentially have greater muscle mass. The great majority of the DNA content of muscle is accumulated during postnatal muscle growth and development, which is the direct result of satellite cell activity (Table 1). Muscle size is determined by the balance between the amount of muscle protein synthesized and the amount of muscle protein degraded. Any possible combination that results in a positive balance in this equation (muscle protein accretion $=$ amount of muscle protein synthesized -amount of muscle protein degraded) will result in muscle hypertrophy.

Scenarios that can lead to muscle hypertrophy:

1. Increased protein synthesis and decreased protein degradation.
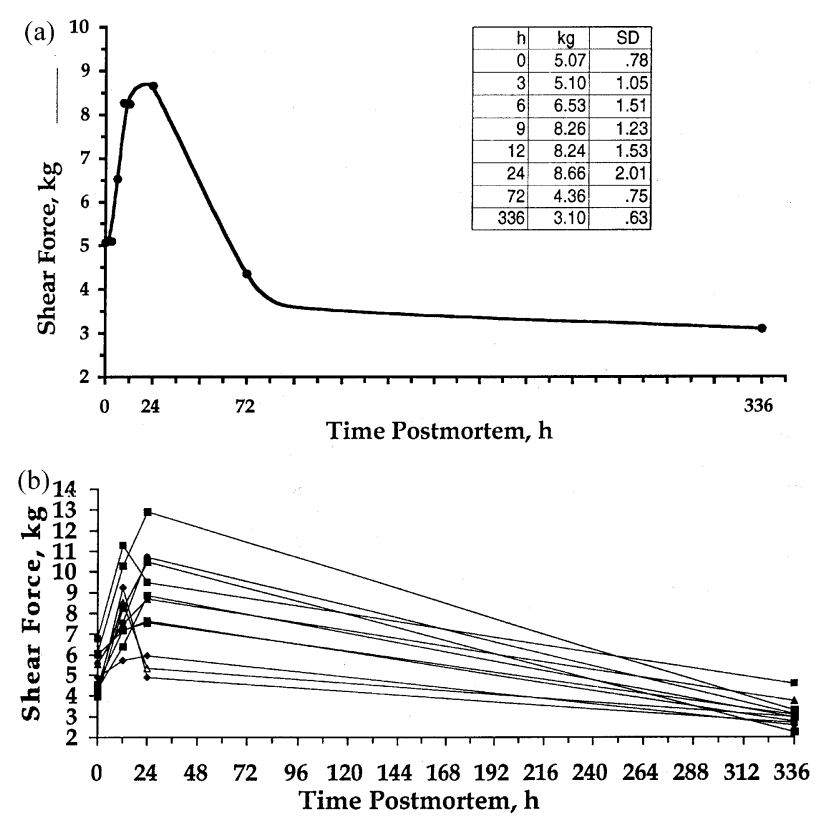

Fig. 1. (a) Effect of postmortem time on Warner-Bratzler shear force of lamb longissimus (Wheeler \& Koohmaraie, 1994). (b) Effect of individual animal and postmortem time on lamb longissimus WarnerBratzler shear force (Wheeler \& Koohmaraie, 1994).

2. Increased protein synthesis and increased protein degradation, providing increase in synthesis is greater than the increase in degradation (least efficient method to increase muscle growth rate).

3. Decreased protein synthesis and decreased protein degradation, providing decrease in protein degradation is greater than the decrease in synthesis (most efficient method to increase muscle growth rate).

As indicated, the contribution of protein synthesis to protein accretion is perhaps just as important as the contribution of protein degradation to protein accretion. However, since the mechanisms of protein synthesis are understood and have been discussed in far greater detail than the mechanisms that regulate muscle protein degradation, herein we will review our current understanding of mechanisms of protein degradation. Furthermore, as will become apparent in this manuscript, because changes in protein synthesis do not affect meat tenderness, a discussion on the mechanisms of protein synthesis would not be relevant to the objectives of this manuscript. However, the relative contribution of both processes, as well as the contribution of hyperplasia and hypertrophy to variation in tenderness of meat after postmortem storage, will be discussed.

Muscle consists of three protein fractions, myofibrillar (salt-soluble), connective tissue (acid soluble), and sarcoplasmic (water-soluble) proteins. The focus of this manuscript will be the regulation of myofibrillar proteins' degradation because myofibrillar proteins are 
Table 1

Postnatal DNA accumulation in skeletal muscle ${ }^{a}$

\begin{tabular}{|c|c|c|c|}
\hline Species, muscle & $\begin{array}{l}\text { Increase in DNA } \\
\text { (X-fold) }\end{array}$ & $\begin{array}{l}\text { Percentage of DNA } \\
\text { accumulated during the } \\
\text { indicated postnatal period }\end{array}$ & Source \\
\hline Pigs, 23-118 kg (Total muscle) & $2-2.7$ & $50-63$ & Harbison et al., 1976 \\
\hline Sheep, 0-120 days, gastronemius & 3.1 & 66 & Johns \& Bergen, 1976 \\
\hline Sheep, 35-77 days, Biceps femoris & 2.6 & 60 & Lorenzen et al., 2000 \\
\hline Sheep (callipyge), 35-77 days, Biceps femoris & 2.6 & 62 & Lorenzen et al., 2000 \\
\hline New Hampshire female chicken, 0-28 days, breast muscle & 16.9 & 94 & Moss et al., 1964 \\
\hline New Hampshire male chicken, 0-266 days, pectoral & 96 & 99 & Moss, 1968 \\
\hline
\end{tabular}

a Adapted and modified from Allen, Merkel, and Young (1979).

the major protein fraction of skeletal muscle and it is the state of myofibrils that explains most of the variation in tenderness of longissimus (the major muscle of economic importance in the United States). This is not to say that connective tissue does not contribute to longissimus tenderness, rather connective tissue determines background toughness (Marsh, 1977) and as such accounts for little of the variation in tenderness of longissimus after 14 days postmortem storage. Also, since sarcoplasmic proteins are not structural proteins, they do not directly affect meat tenderness.

Goll, Kleese, and Szpacenko (1989) demonstrated the importance of protein degradation to the efficiency of lean mass deposition. They demonstrated that a $10 \%$ reduction in the rate of protein degradation (from 3\% per day to $2.7 \%$ per day) would result in a doubling of the rate of gain in a hypothetical 454-kg bovine animal. The ability to decrease the rate of protein degradation at a fraction of what Goll et al. (1989) demonstrated would result in significant increases in efficiency of muscle protein deposition. Hence, elucidating the factors that regulate myofibrillar protein degradation during growth and development and, more importantly, developing the ability to advantageously manipulate these factors would allow significant increases in production efficiency.

\subsection{Mechanism of myofibrillar protein turnover}

The complex process of breakdown of myofibrillar proteins and the causative agents involved remain poorly understood. There is indirect evidence of the mechanisms of myofibrillar protein degradation as well as the causative agents for myofibrillar protein degradation. However, there is no direct evidence to support these widely held and plausible hypotheses. Evidence would be considered direct if manipulation of the proposed causative agent resulted in observed changes in protein degradation.

Perhaps the best model for turnover of myofibrillar protein is the theoretical model presented by Goll, Thompson, Taylor, and Christiansen (1992). According to Goll et al. (1992), for muscle to remain functional, the process must occur at the surface of the myofibrils and the first step in the turnover of myofibrillar proteins in mature skeletal muscle cells is probably disassembly of myofibrils into myofilaments. This may or may not be a rate-limiting step. These myofilaments are subsequently degraded to polypeptides and ultimately to free amino acids. The best evidence to support the above proposal is the observation that incubation of isolated myofibrils from several rat muscles in a relaxing solution released a small amount of myofilaments that constituted less than $5 \%$ of the total myofibrillar proteins (Etlinger, Zad, Fischman, \& Rabinowitz, 1975). Because this population of myofilaments was easily removed, Etlinger and coworkers named them the Easily Released Myofilaments (ERM). With respect to protein composition (Reville, Murray, Ahern, \& Zeece, 1994; van der Westhuyzen, Matsumoto, \& Etlinger, 1981), ERM have remarkable resemblance to the myofilaments that would be released from myofibrils in the Goll et al. (1992) proposal. Treatment that enhances myofibrillar protein turnover increases the ERM fraction (Dahlmann, Kuehn, \& Reinauer, 1986). Additionally, ERM levels in muscle increase in response to treatment that increases calpain activity (Belcastro, Scrubb, \& Gilchrist, 1991; Dahlmann et al., 1986; Reville et al., 1994; van der Westhuyzen et al., 1981).

Although a plausible hypothesis with some experimental evidence to support it, as stated by Goll, Thompson, Taylor, and Ouali (1998), the problem is that this proposal does not account for the turnover of proteins in the interior of the myofibrils. Unless the entire myofibril is turned over, this proposal would indicate that the interior proteins are immortal.

With respect to proteases that have the potential to play a key role in the removal of myofilaments and generation of free amino acids, there are three candidates: calpain, proteasome, and the lysosomal proteolytic systems. The Goll et al. (1992) hypothesis states that because the calpain system is the only proteolytic system capable of making the very specific cleavages needed to release myofilaments, it is the best candidate to initiate 
the removal of myofilaments from the surface of the myofibrils. Through a yet-to-be-identified proteolytic pathway, these myofilaments are then degraded into individual proteins. Lysosomal enzymes and/or the proteasome complex will degrade these individual proteins into amino acids (Goll et al., 1998). The Goll et al. (1992) proposal stated that the proteasome complex is a good candidate to degrade the released myofilaments into amino acids. However, because it was demonstrated that proteasome is not able to degrade myofibrils (Koohmaraie, 1992a) or any complex of myofibrillar proteins (other than individual proteins; Solomon \& Goldberg, 1996), the proteasome cannot be involved in degradation of myofilaments into proteins. However, once the myofilaments are disassembled into individual proteins, both lysosomal cathepsins and the proteasome are capable of rapidly converting myofibrillar proteins into amino acids.

The calpain proteolytic system consists of a ubiquitous system ( $\mu$-calpain, m-calpain and calpastatin) and a tissue-specific calpain, which has been referred to as p94, calpain 3, or nCL-1 (Suzuki, Sorimachi, Yoshizawa, Kinbara, \& Ishiura, 1995). In spite of some recent publications (Ilian, Bekhit, \& Bickerstaffe, 2001; Ilian, Morton, et al., 2001) we have not discussed or assigned a role for calpain 3 in either muscle growth or meat tenderness. The bases for our decisions are described below. First, although calpain 3 has 10 -fold more mRNA in muscle cells than $\mu$-calpain or m-calpain, the calpain 3 enzyme has never been identified. Hence there is no information with regard to its structure, function, or proteolytic activity. Second, the publications that have assigned a role for calpain 3 in meat tenderization/ tenderness have either used mRNA abundance or have used an antibody generated against a protein based on calpain 3 mRNA sequence (Ilian, Bekhit, \& Bickerstaff, 2001; Ilian, Morton, et al., 2001; Parr et al., 1999). These antibodies react with a polypeptide with molecular mass of $94 \mathrm{kDa}$. However, the protein recognized by these antibodies has not been sequenced to confirm its identity. The reaction of antibodies with the polypeptide could simply be an artifact. Indeed several groups have used this approach. Among them are Goll and associates. According to Darrel Goll (personal communication) they have generated several such antibodies based on calpain 3 mRNA sequence that reacted with a polypeptide with molecular mass of $94 \mathrm{kDa}$ in skeletal muscle, but sequencing demonstrated the reaction was an artifact (i.e. the polypeptide with molecular mass of $94 \mathrm{kDa}$ was not calpain 3). Third, in humans, mutations in the calpain 3 gene are associated with the development of limb girdle muscular dystrophy type $2 \mathrm{a}$, a condition that is associated with excessive protein catabolism (Richard et al., 1995, 1999). The mutation in calpain 3 that results in limb girdle muscular dystrophy causes loss of catalytic activity of calpain 3 (Ono et al.,
1998). In other words, inactivation of calpain 3 is responsible for excessive protein degradation that leads to this form of muscular dystrophy. A protease that is involved in the regulation of muscle protein degradation in live animals or postmortem muscle would have opposite characteristics. And finally, despite wide variation in shear force values, Parr et al. (1999) found no evidence that supports a role for calpain 3 abundance and postmortem stability in pork tenderness.

\section{Meat tenderness}

Before discussing the relationship between the mechanisms of muscle protein degradation and meat tenderness, it is appropriate to provide a summary of the biological basis for meat tenderness variation (for reviews see Koohmaraie, 1992b, 1994, 1996). We demonstrated that lamb longissimus has intermediate shear force values immediately after slaughter, toughens during the first $24 \mathrm{~h}$, and then becomes tender during postmortem storage at $4^{\circ} \mathrm{C}$. Because sarcomere length decreased (from mean at-death lengths of $2.24 \mu \mathrm{m}$ to mean $24 \mathrm{~h}$ postmortem lengths of $1.69 \mu \mathrm{m}$ ) as shear force increased and because shear force value does not increase during rigor development when muscle is prevented from shortening, we concluded that sarcomere shortening during rigor development is the cause of lamb longissimus toughening from 0 to $24 \mathrm{~h}$ postmortem (Koohmaraie, Doumit, \& Wheeler, 1996; Wheeler \& Koohmaraie, 1994). However, as discussed earlier and indicated in Fig. 1b, these processes are highly variable among individual carcasses.

The tenderization process is estimated to begin soon after slaughter (perhaps as soon as $3 \mathrm{~h}$, but it is highly variable among individual carcasses) (Veiseth, Shackelford, Wheeler, \& Koohmaraie, 2001; Koohmaraie, unpublished data). Current evidence suggests that proteolysis of key myofibrillar proteins is the cause of meat tenderization. These proteins are involved in: (1) inter-myofibril linkages (e.g., desmin and vinculin), (2) intra-myofibril linkages (e.g., titin, nebulin, and possibly troponin-T), (3) linking myofibrils to sarcolemma by costameres (e.g. vinculin and dystrophin), and (4) the attachment of muscle cells to the basal lamina (e.g. laminin and fibronectin). The function of these proteins is to maintain the structural integrity of myofibrils (for review see Price, 1991). Proteolytic degradation of these proteins would cause weakening of myofibrils and, thus, tenderization.

Sarcomere length, connective tissue content, and proteolysis of myofibrillar proteins account for most, if not all, of the explainable variation observed in tenderness of aged meat (after postmortem storage). However, the relative contribution of each of the above components of tenderness is muscle dependent. For example, while 
sarcomere length is the major determinant of psoas major tenderness, proteolysis is the major determinant of longissimus tenderness and connective tissue content is a major contributor to tenderness of muscles such as biceps femoris and semimembranosus.

\section{Meat tenderness and muscle growth}

If muscle growth is the result of hyperplasia (increase in cell number during embryonic development and/or increase in DNA content due to satellite cell activity), no negative effect or maybe even a positive effect (see later) on meat tenderness is expected. The best example to support the above statement is the case of doublemuscled cattle. Double muscling in cattle is the result of an inactivating mutation in the myostatin gene (Grobet et al., 1997; Kambadur, Sharma, Smith, \& Bass 1997; McPherron, Lawler, \& Lee, 1997; McPherron \& Lee, 1997; Smith, Lopez-Carrales, Kappes, \& Sonstegard, 1997), resulting in suppression of inhibition of embryonic cell proliferation (hence, animals are born with increased muscle fiber numbers). Double-muscled animals also have a greater capacity to synthesize muscle proteins. Cattle with one copy of inactivated myostatin, relative to cattle without inactivated myostatin, will yield about a $7 \%$ increase in retail product yield and two copies of mutated myostatin will result in about $20 \%$ increase in retail product yield (Fig. 2a; Wheeler, Shackelford, Casas, Cundiff, \& Koohmaraie, 2001). Moreover, meat from cattle carrying inactivated myostatin is more tender in most muscles, especially in muscles in which connective tissue content is the major tenderness determinant (Fig. 2b; Wheeler et al., 2001). Also, if muscle hypertrophy were due to changes in protein synthesis, there would not be a negative effect on meat tenderness because factors that regulate protein synthesis are not involved in the regulation of meat tenderness and tenderization. Double-muscled cattle are an example of the effect of protein synthesis on meat tenderness. Of all the possible mechanisms of increasing muscle deposition, only the mechanism that involves suppression of protein degradation will result in decreased meat tenderness. Unfortunately, suppression of protein degradation seems to be the mechanism that is responsible for differences in the rates of muscle growth in domestic animals (Bohorov, Buttery, Correia, \& Soar, 1987; Koohmaraie, Killefer, et al., 1995; Maruyama, Sunde, \& Swick, 1978; Reeds, Hay, Dorwood, \& Palmer, 1986). The best examples in support of the negative effects of the suppression of myofibrillar protein degradation on meat tenderness are two welldocumented cases. The first is a genetic mutation in sheep called callipyge and the second is nutritional manipulation and dietary administration of various $\beta$-adrenergic agonists (BAA) in some species (e.g.,
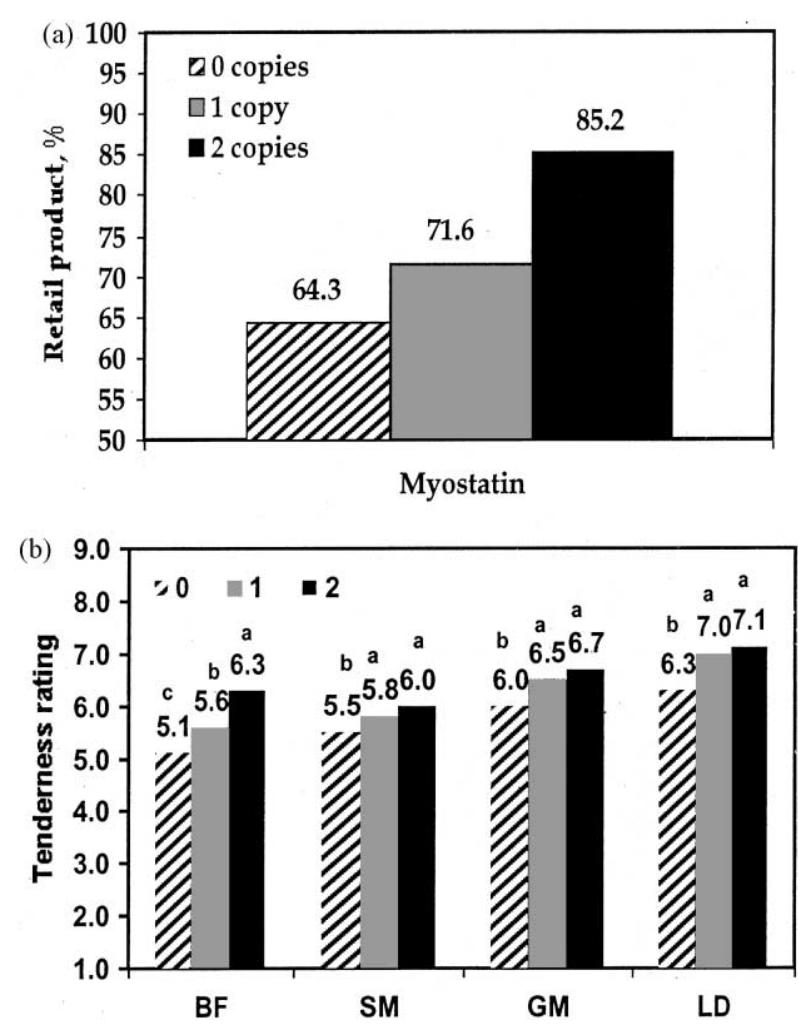

Fig. 2. (a) Effect of myostatin on retail product yield. SD are 4.0, 4.1, and $2.4 \%$, respectively for 0,1 , and 2 copies (Wheeler et al., 2001). (b) Effects of muscle and myostatin on trained sensory tenderness rating. SD are $0.8,0.8$, and $0.8(\mathrm{BF}), 0.9,0.9$, and $1.0(\mathrm{SM}), 0.8,0.7$, and 0.7 (GM), and 1.0, 0.7, and 0.9 (LD), respectively, for 0,1 , and 2 copies (Wheeler et al., 2001).

Cimaterol, $\mathrm{L}_{644,969}$, and Clenbuterol in most meat producing species).

Callipyge is a well-studied and documented phenotype in sheep (Carpenter, Rice, Cockett, \& Snowder, 1996; Cockett et al., 1994; Freking et al., 1998; Jackson, Miller, \& Green, 1997; Koohmaraie, Shackelford, Wheeler, Lonergan, \& Doumit, 1995). The characteristics of callipyge that relate to this manuscript are: (1) in market weight lambs, callipyge-induced muscle hypertrophy is maintained by reduced protein degradation (Fig. 3; Lorenzen et al., 2000); (2) the relative effect of the callipyge condition on weights of various muscles is proportional $\left(R^{2}=0.91\right)$ to the relative effect of the callipyge condition on calpastatin activity (Fig. 4; Koohmaraie, Shackelford, et al., 1995), and (3) the toughness of callipyge meat results from reduced rate and extent of postmortem proteolysis and tenderization (Koohmaraie, Shackelford, et al., 1995).

The effects of dietary administration of BAA on muscle growth and meat tenderness are remarkably similar to the effect of the callipyge gene on muscle growth and meat tenderness. Feeding of $\mathrm{L}_{644,969}$ to lambs increased muscle mass, increased calpastatin activity, reduced postmortem proteolysis, increased meat toughness, and virtually prevented tenderization 
during postmortem storage (Koohmaraie, Shackelford, Muggli-Cockett, \& Stone, 1991; Koohmaraie, Shackelford, \& Wheeler, 1996; Kretchmar, Hathaway, Dayton, \& Epley, 1990).

Callipyge and BAA data provide the best evidence available to associate the negative effects of increased muscle hypertrophy via reduced protein degradation and meat tenderness. The hypothesis is that in living muscle, elevation of calpastatin suppresses $\mu$-calpain (and perhaps m-calpain), which in turn reduces the rate of protein degradation resulting in an increase in muscle growth. The negative effects of calpastatin on the rate

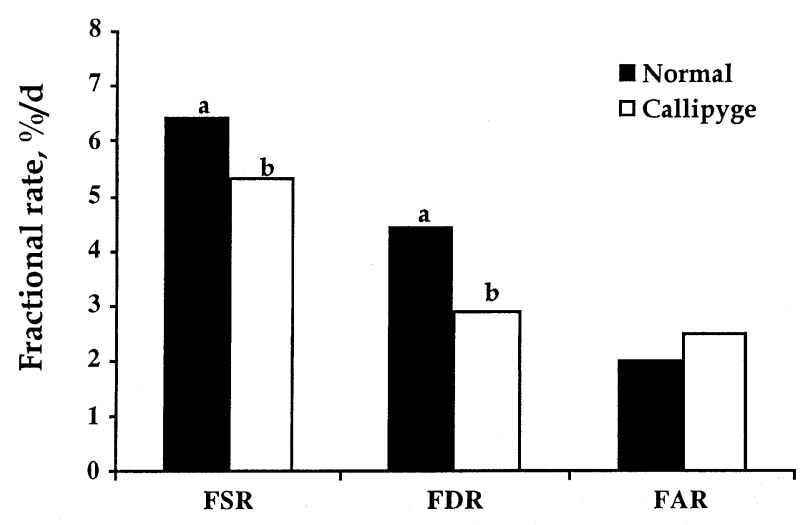

Biceps femoris

Fig. 3. Fractional protein synthesis (FSR), degradation (FDR), and accretion (FAR) rates in normal and callipyge lamb (Lorenzen et al., 2000). and extent of postmortem proteolysis and meat tenderness are now well documented (Koohmaraie, Killefer et al., 1995).

The importance discussed earlier of recognizing that the relative contribution of sarcomere length, postmortem proteolysis, and collagen concentration to ultimate meat tenderness is muscle dependent is supported by the callipyge model. If muscle hypertrophy were caused by reduced protein degradation, we would expect increased meat toughness to occur only in hypertrophied muscles whose tenderness is affected by changes in postmortem proteolysis (e.g., longissimus). For instance, postmortem proteolysis has little effect on the tenderness of psoas major because psoas major has very long sarcomeres. Consequently, the callipyge mutation does not affect psoas major tenderness (Shackelford, Wheeler, \& Koohmaraie, 1997), in spite of the reduced rate and extent of postmortem proteolysis. Because psoas major has extremely long sarcomeres (when the carcass is hung by the Achilles tendon), regardless of the genetic mutation or dietary treatment it will always be tender. In fact, it is impossible to find psoas major that is not tender (when the carcass is hung by the Achilles tendon).

Based on the discussions in the preceding paragraphs, there are two calpain-mediated approaches to improve muscle growth. If the objective is to increase muscle mass without any regard for meat tenderness (for the production of ground beef or tenderness enhanced products), one can select for animals with high calpastatin

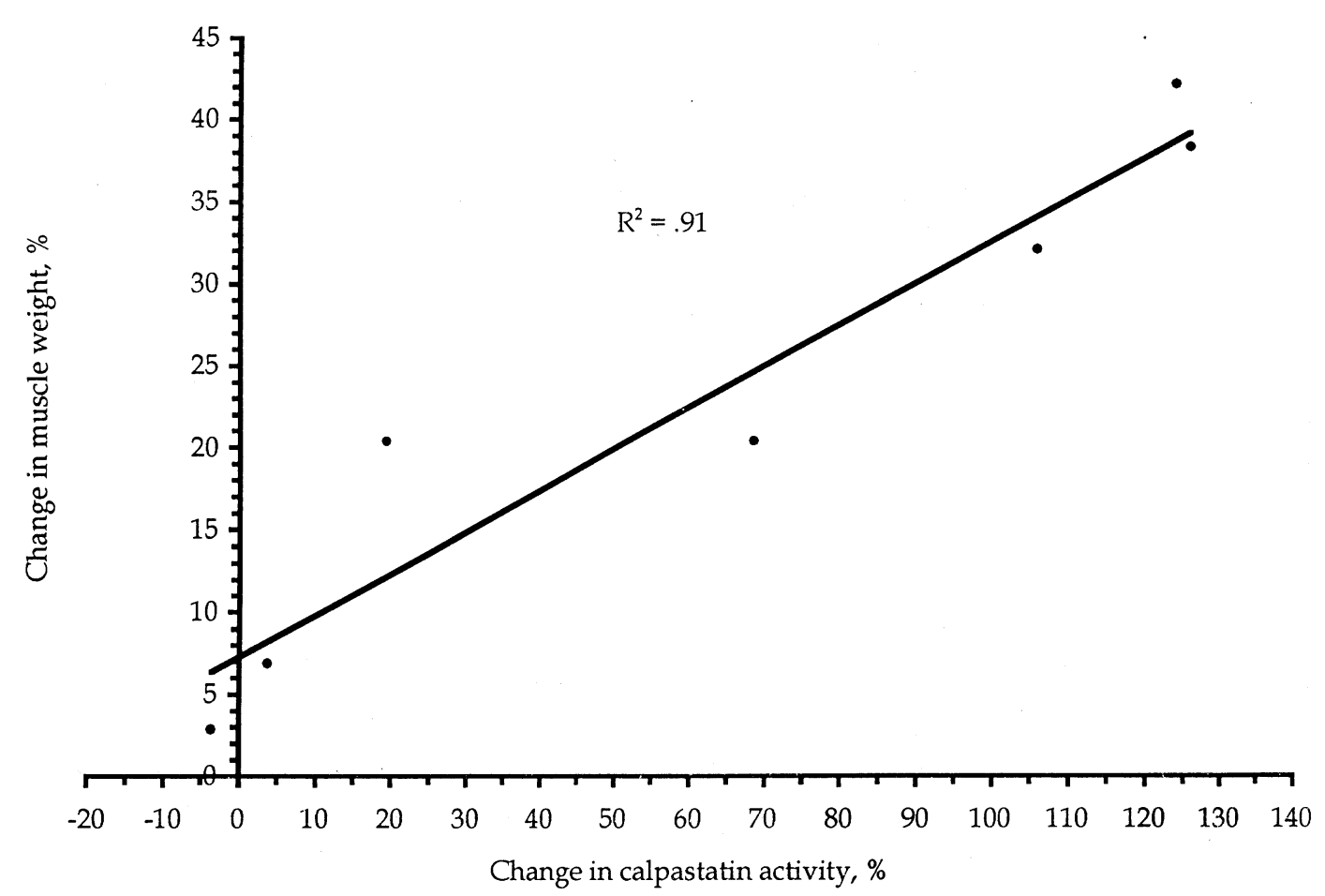

Fig. 4. The relationship between changes in muscle calpastatin activity and changes in muscle mass in callipyge lambs (Koohmaraie, Shackelford, et al., 1995). 
activity. If the objective is to increase muscle growth without any adverse effect on meat quality, then a transgenic approach would be most appropriate. In the case of transgenics, one could produce animals with the ability to overexpress calpastatin in skeletal muscle during animal growth and then stop calpastatin overexpression just before animals are presented for slaughter. The reason for focusing on calpain-mediated approaches is that suppression of protein degradation without any effect on protein synthesis is energetically efficient. Of course, there are non-calpain-mediated approaches that can be explored to increase muscle mass. For example, one could explore the possibility of selection for animals with higher satellite cell activity.

\section{Conclusions}

Although indirect evidence supports the proposed mechanisms of myofibrillar protein turnover and the pivotal role that calpain plays in this process, it is important to note that there is no direct evidence in support of this theory. Hence, it is important to be able to design and execute the appropriate experiments that directly substantiate this proposal. In our assessment, we have to develop an experimental system that would allow exclusive manipulation of the calpain proteolytic system (without wholesale changes in other biological systems/pathways which appears to occur in callipyge and BAA feeding) followed by quantification of myofibrillar protein turnover. If, indeed, the calpain proteolytic system is a rate-limiting step in turnover of myofibrillar proteins, manipulation of the calpain proteolytic system should result in changes in myofibrillar protein degradation. Conclusive demonstration of this hypothesis could have a far reaching impact on the animal industry and any other industry that is affected by the ability to regulate muscle protein degradation.

\section{Acknowledgements}

We are grateful to Marilyn Bierman and Carol Grummert for secretarial assistance.

\section{References}

Allen, R. E., Merkel, R. A., \& Young, R. B. (1979). Cellular aspects of muscle growth: myogenic cell proliferation. Journal of Animal Science, 49, 115-127.

Belcastro, A. N., Scrubb, J., \& Gilchrist, J. S. (1991). Regulation of ATP-stimulated releasable myofilaments from cardiac and skeletal muscle myofibrils. Molecular and Cellular Biochemistry, 103, 113-120.

Bohorov, O., Buttery, P. J., Correia, J. H. R. D., \& Soar, J. B. (1987). The effect of the $\beta$-2-adrenergic agonist clenbuterol or implantation with oestradiol plus trenbolone acetate on protein metabolism in wether lambs. British Journal of Nutrition, 57, 99-107.
Carpenter, C. E., Rice, O. D., Cockett, N. E., \& Snowder, G. D. (1996). Histology and composition of muscles from normal and callipyge lambs. Journal of Animal Science, 74, 388-393.

Cockett, N. E., Jackson, S. P., Shay, T. L., Nielsen, D., Moore, S. S., Steele, M. R., Barendse, W., Green, R. D., \& Georges, M. (1994). Chromosomal localization of the callipyge gene in sheep (Ovis aries) using bovine DNA markers. Proceedings of the National Academy of Sciences USA, 91, 3019-3123.

Dahlmann, B., Kuehn, L., \& Reinauer, H. (1986). Identification of two alkaline proteinases from rat skeletal muscle. In V. Tur (Ed.), Cysteine proteinases and their inhibitors (pp. 133-146). New York: Walter de Guyter.

Etlinger, J. D., Zak, R., Fischman, D. A., \& Rabinowitz, M. (1975). Isolation of newly synthesized myosin filaments from skeletal muscle homogenates and myofibrils. Nature, 255, 259-261.

Freking, B. A., Keele, J. W., Beattie, C. W., Kappes, S. M., Smith, T. P. L., Sonstegard, T. S., Nielsen, M. K., \& Leymaster, K. A. (1998). Evaluation of the ovine callipyge locus: I. Relative chromosomal position and gene action. Journal of Animal Science, 76, 2062-2071.

Goll, D. E., Kleese, W. C., \& Szpacenko, A. (1989). Skeletal muscle proteases and protein turnover. In D. R. Campion, G. J. Hausman, \& R. J. Martin (Eds.), Animal growth regulation (pp. 141-182). New York: Plenum Publishing.

Goll, D. E., Thompson, V. F., Taylor, R. G., \& Christiansen, J. A. (1992). Role of the calpain system in muscle growth. Biochimie, 74, 225-237.

Goll, D. E., Thompson, V. F., Taylor, R. G., \& Ouali, A. (1998). The calpain system and skeletal muscle growth. Canadian Journal of Animal Science, 78, 503-512.

Grobet, L., Martin, L. J. R., Poncelet, D., Pirottin, D., Brouwers, B., Riquet, J., Schoeberlein, A., Dunner, S., Ménissier, F., Massabanda, J., Fires, R., Hanset, R., \& Georges, M. (1997). A deletion in the bovine myostatin gene causes the double-muscled phenotype in cattle. Nature Genetics, 17, 71-74.

Harbison, S. A., Goll, D. E., Parrish, F. C. Jr., Wang, V., \& Kline, E. A. (1976). Muscle growth in two genetically different lines of swine. Growth, 40, 253.

Ilian, M. A., Bekhit, A. E., \& Bickerstaffe, R. (2001). Catalysis of meat tenderization during postmortem aging by calpain 3 (p94). Journal of Animal Science, 79(Suppl. 1), 437.

Ilian, M. A., Morton, J. D., Kent, M. P., Le Couteur, C. E., Hickford, J., Cowley, R., \& Bickerstaffe, R. (2001). Intermuscular variation in tenderness: association with the ubiquitous and muscle-specific calpains. Journal of Animal Science, 79, 122-132.

Jackson, S. P., Miller, M. F., \& Green, R. D. (1997). Phenotypic characterization of Rambouillet sheep expressing the callipyge gene: II. Carcass characteristics and retail yield. Journal of Animal Science, 75, 125-132.

Johns, J. T., \& Bergen, W. G. (1976). Growth in sheep. Pre- and postweaning hormone changes and muscle and liver development. Journal of Animal Science, 43, 192-200.

Kambadur, R., Sharma, M., Smith, T. P. L., \& Bass, J. J. (1997). Mutations in myostatin GDF8 in double-muscled Belgian Blue and Piedmontese cattle. Genome Research, 7, 910-915.

Koohmaraie, M. (1992a). Ovine skeletal muscle multicatalytic proteinase complex (proteasome): purification, characterization, and comparison of its effects on myofibrils with $\mu$-calpain. Journal of Animal Science, 70, 3697-3708.

Koohmaraie, M. (1992b). Role of the neutral proteinases in postmortem muscle protein degradation and meat tenderness. Proceedings of the Reciprocal Meat Conference, 45, 63.

Koohmaraie, M. (1994). Muscle proteinases and meat aging. Meat Science, 36, 93-104.

Koohmaraie, M. (1995). The biological basis of meat tenderness and potential genetic approaches for its control and prediction. Proceedings of the Reciprocal Meat Conference, 48, 69-75. 
Koohmaraie, M. (1996). Biochemical factors regulating the toughening and tenderization processes of meat. Meat Science, 43, S193-S201.

Koohmaraie, M., Doumit, M. E., \& Wheeler, T. L. (1996). Meat toughening does not occur when rigor shortening is prevented. Journal of Animal Science, 74, 2935-2942.

Koohmaraie, M., Killefer, J., Bishop, M. D., Shackelford, S. D., Wheeler, T. L., \& Arbona, J. R. (1995). Calpastatin-based methods for predicting meat tenderness. In A. Ouali, D. Demeyer, \& F. Smulders (Eds.), Expression of tissue proteinases and regulation of protein degradation as related to meat quality (pp. 395-412). Utrecht, The Netherlands: EECEAMST.

Koohmaraie, M., Shackelford, S. D., Muggli-Cockett, N. E., \& Stone, R. T. (1991). Effect of the $\beta$-adrenergic agonist, L644,969, on muscle growth, endogenous proteinase activities and postmortem proteolysis in wether lambs. Journal of Animal Science, 69, 4823-4835.

Koohmaraie, M., Shackelford, S. D., \& Wheeler, T. L. (1996). Effects of a $\beta$-adrenergic agonist $(\mathrm{L}-644,969)$ and male sex condition on muscle growth and meat quality of callipyge lambs. Journal of Animal Science, 74, 70-79.

Koohmaraie, M., Shackelford, S. D., Wheeler, T. L., Lonergan, S. M., \& Doumit, M. E. (1995). A muscle hypertrophy condition in lamb (callipyge): characterization of effects on muscle growth and meat quality traits. Journal of Animal Science, 73, 3596-3607.

Kretchmar, D. H., Hathaway, M. R., Dayton, R. J., \& Epley, W. R. (1990). Alterations in postmortem degradation of myofibrillar proteins in muscle of lambs fed a $\beta$-adrenergic agonist. Journal of Animal Science, 68, 1760-1772.

Lorenzen, C. L., Koohmaraie, M., Shackelford, S. D., Jahoor, F., Freetly, H. C., Wheeler, T. L., Savell, J. W., \& Fiorotto, M. L. (2000). Protein kinetics in callipyge lambs. Journal of Animal Science, 78, 78-87.

Marsh, B. B. (1977). The nature of tenderness. Proceedings of the Reciprocal Meat Conference, 30, 69-74.

Maruyama, K., Sunde, M. L., \& Swick, R. W. (1978). Growth and muscle protein turnover in the chick. Biochemistry, 716, 573-582.

McPherron, A. C., Lawler, A. M., \& Lee, S.-J. (1997). Regulation of skeletal muscle mass in mice by a new TGF-B(beta) superfamily member. Nature, 387, 83-90.

McPherron, A. C., \& Lee, S.-J. (1997). Double muscling in cattle due to mutations in the myostatin gene. Proceedings of the National Academy of Sciences USA, 94, 12457-12461.

Moss, F. P. (1968). The relationship between the dimensions of fibres and the number of nuclei during normal growth of skeletal muscle in the domestic fowl. American Journal of Anatomy, 122, 555-564.

Moss, F. P., Simmonds, R. A., \& McNary, H. W. (1964). The growth and composition of skeletal muscle in the chicken. 2. The relationship between muscle weight and the number of nuclei. Poultry Science, 43, 1086-1091.

Ono, Y., Shimada, H., Sorimachi, H., Richard, I., Saido, T. C., Beckmann, J. S., Ishiura, S., \& Suzuki, K. (1998). Functional defects of a muscle-specific calpain, p94, caused by mutations associated with limb-girdle muscular dystrophy type 2A. Journal of Biological Chemistry, 273, 17073-17078.
Parr, T., Sensky, P. L., Scothern, G. P., Bardsley, R. G., Buttery, P. J., Wood, J. D., \& Warkup, C. (1999). Relationship between skeletal muscle-specific calpain and tenderness of conditioned porcine longissimus muscle. Journal of Animal Science, 77, 661-668.

Price, M. G. (1991). Striated muscle endosarcomeric and exosarcomeric lattices. Advances in Structural Biology, 1, 175-207.

Reeds, P. J., Hay, S. M., Dorwood, P. M., \& Palmer, R. M. (1986). Stimulation of muscle growth by clenbuterol: lack of effect on muscle protein biosynthesis. British Journal of Nutrition, 56, 249-258.

Reville, W. J., Murray, B. A., Ahern, S., \& Zeece, M. G. (1994). Easily releasable myofilaments in post mortem bovine muscle. Scienza deli'Alimentazione, 14, 431-440.

Richard, I., Broux, O., Allamand, V., Fougerousse, F., Chiannilkulchai, N., Bourg, N., Brenguier, L., Devaud, C., Pasturaud, P., \& Roudaut, C. (1995). Mutations in the proteolytic enzyme calpain3 cause limb-girdle muscular dystrophy type 2A. Cell, 81, 27-40.

Richard, I., Roudaut, C., Saenz, A., Pogue, R., Grimbergen, J. E., Anderson, L. V., Beley, C., Cobo, A. M., de Diego, C., Eymard, B., Gallano, P., Ginjaar, H. B., Lasa, A., Pollitt, C., Topaloglu, H., Urtizberea, J. A., de Visser, M., van der Kooi, A., Bushby, K., Bakker, E., Lopez de Munain, A., Fardeau, M., \& Beckmann, J. S. (1999). Calpainopathy-a survey of mutations and polymorphisms. American Journal of Human Genetics, 64, 1524-1540.

Shackelford, S. D., Wheeler, T. L., \& Koohmaraie, M. (1997). Effect of the callipyge phenotype and cooking method on tenderness of several major lamb muscles. Journal of Animal Science, 75, 21002105.

Smith, T. P. L., Lopez-Corrales, N. L., Kappes, S. M., \& Sonstegard, T. S. (1997). Myostatin maps to the interval containing the bovine mh locus. Mammalian Genome, 8, 742-744.

Solomon, V., \& Goldberg, A. L. (1996). Importance of the ATP-ubiquitin-proteasome pathway in the degradation of soluble and myofibrillar proteins in rabbit muscle extracts. Journal of Biological Chemistry, 271, 26690-26697.

Suzuki, K., Sorimachi, H., Yoshizawa, T., Kinbara, K., \& Ishiura, S. (1995). Calpain: novel family members, activation and physiological function. Biological Chemistry Hoppe-Seyler, 376, 523-529.

van der Westhuyzen, D. R., Matsumoto, K., \& Etlinger, J. D. (1981). Easily releasable myofilaments from skeletal and cardiac muscles maintained in vitro. Role in myofibrillar assembly and turnover. Journal of Biological Chemistry, 256, 11791-11797.

Veiseth, E., Shackelford, S. D., Wheeler, T. L., \& Koohmaraie, M. (2001). Effect of postmortem storage on m-calpain and $\mu$-calpain in ovine skeletal muscle. Journal of Animal Science, 79, $1502-1508$.

Wheeler, T. L., \& Koohmaraie, M. (1994). Prerigor and postrigor changes in tenderness of ovine longissimus muscle. Journal of Animal Science, 72, 1232-1238.

Wheeler, T. L., Shackelford, S. D., Casas, E., Cundiff, L. V., \& Koohmaraie, M. (2001). The effects of Piedmontese inheritance and myostatin genotype on the palatability of longissimus thoracis, gluteus medius, semimembranosus, and biceps femoris. Journal of Animal Science, 79, 3069-3074. 